\title{
E. SVEIKATOS PASLAUGŲ NAUDOTOJO PORTRETAS LIETUVOJE
}

\author{
Eglè Caronkute் \\ Mykolo Romerio universiteto Politikos ir vadybos fakulteto \\ Vadybos institutas \\ Valakupių g. 5, LT-10101 Vilnius, Lietuva \\ Elektroninis paštas egcaronkut@stud.mruni.eu
}

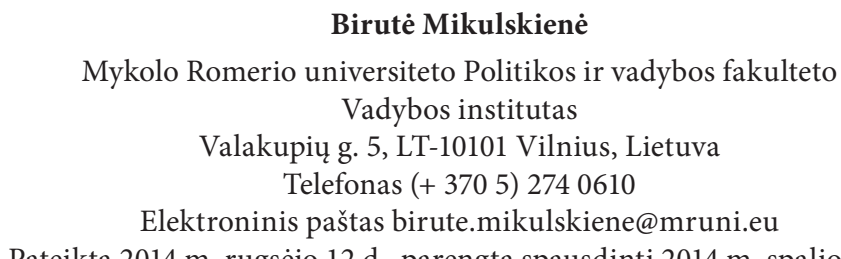

Pateikta 2014 m. rugsèjo 12 d., parengta spausdinti 2014 m. spalio 13 d.

doi:10.13165/SPV-14-2-7-02

\section{Santrauka}

Ivadas. Lietuvos e. sveikatos sistemos plètra išgyveno ne viena iššūkị ir nesèkmę, kai ¿̇dètos pastangos neatneše tikètinų rezultatu, tačiau taip pat reikia pripažinti ir nemenkus proveržius kuriant atskiras jos dalis. Vis dèlto norint kryptingai tobulinti e. sveikatos sistema ir padidinti gyventoju naudojimąi e. sveikatos paslaugomis, reikia turèti specifiniu žiniu apie sistemos trūkumus. Geriausiai veikiančios e. sveikatos prieinamuma atspindi naudotojai ir ju noras naudotis sukurtomis sistemomis. Naudotojo portretas, kaip detalus naudotojo aprašymas, atskleidžia büdingus tam tikros tikslinès naudotojų grupès bruožus ir leidžia prognozuoti kitu naudotojų elgesị ateityje. Naudotojo portretas yra viena iš pripažintų e. paslaugos tinkamumo gerinimo priemonių.

Tikslas. Straipsnyje pateikto tyrimo tikslas yra nustatyti e. sveikatos paslaugu Lietuvoje naudotojo portreta, išsiaiškinant, koki e. sveikatos paslaugu naudotojo portreta tenkina dabartine e. sveikatos sistema Lietuvoje.

Metodai ir duomenys. Siekiant nustatyti e. sveikatos paslaugu naudotojo portreta Lietuvoje, tyrimo metu apklausti gyventojai, kurie žino e. sveikatos paslaugas ir jomis naudojasi Lietuvoje. Tyrimui panaudoti igyvendinant projekta „E-sveikatos pletros integruotos transformacijos: suinteresuotuju pusiu tinklo perspektyva" VP13.1-ŠMM-07-K-02-029/2013 atlikto kiekybinio gyventoju apklausos tyrimo empiriniai duomenys. Analizei atlikti taikytas antrinés kiekybiniu duomenu analizés metodas. 
Statistine duomenu analizè buvo atlikta naudojant statistiniu duomenu apdorojimo paketa „SPSS“ (17 versija), taip pat „WinPepi“ bei „Microsoft Excel 2010“ programas. Naudojimasis paslaugomis buvo analizuojamas atsižvelgiant $i$ gyventoju socialiniusdemografinius rodiklius, $t$. $y$. lytį, gyvenamaja vieta, amžiu, išsilavinima, užimtuma, šeimine padètị bei šeimos dydi ir pajamas. Taip pat atsižvelgta ị pacientu naudojimosi sveikatos priežiūros paslaugomis dažnị bei tai, kokiose asmens sveikatos priežiūros įstaigose (toliau - ASPI) gyventojai lankosi dažniau - privačiose ar valstybinèse.

Rezultatai. Nustatyti dviejų rūšiu sveikatos paslaugų naudotoju portretai: e. sveikatos paslaugu naudotoju portretai bei dažnai sveikatos priežiūros paslaugomis besinaudojančio gyventojo portretas. Galima pastebeti, kad e. sveikatos paslaugų naudotojo ir dažnai sveikatos priežiūros paslaugomis besinaudojančiojo gyventojo portretai yra labai skirtingi. Portretu tyrimai parodè, kad egzistuoja gan objektyvūs socialiniai-demografiniai netolygumai tarp e. sveikatos paslaugu naudotojų, kurie aiškiai rodo netolygumus ir e. sveikatos pletroje. E. sveikatos paslaugos kokybiškiau veikia dideliuose miestuose, kokybiškesne interneto prieiga yra pasiekiama didesniu pajamu, aukštesnio išsilavinimo ir jaunesniu gyventoju grupei. Tuo tarpu e. paslaugu poreikis kitoms amžiaus grupems yra net labiau reikalingas dèl didesnio sveikatos paslaugu poreikio. Tad socialnių-demografiniu portretų netolygumu stebėsena leidžia nustatyti e. sveikatos sistemos vystymosi spragas, kurios siūlytinos tobulinti pirmiausia.

Reikšminiai žodžiai: e. sveikata, e. sveikatos paslaugos, naudotojo portretas.

\section{Ivadas}

E. sveikata - sveikatos apsaugos, medicinos informatikos ir administracinès veiklos visuma, užtikrinama diegiant informacines ir ryšių technologijas, organizacines veiklos naujoves ir naujus igūdžius ir skirta sveikatinimo (asmens, visuomenès, farmacijos) paslaugoms tobulinti operatyviai pateikiant išsamią veiklai reikalingą informaciją. Šiuo metu Lietuvoje yra igyvendinama „Lietuvos e. sveikatos 2007-2015 metų plètros strategija“, o nuo 2014 m. pradžios prasidèjo paskutinis Strategijos igyvendinimo etapas ${ }^{1,2}$.

Lietuvos e. sveikatos sistemos plètra išgyveno ne vieną iššūkị ir nesėkmę, kai ịdètos pastangos neatnešè tikètinų rezultatų, tačiau taip pat reikia pripažinti ir nemenkus proveržius kuriant atskiras jos dalis. Šiuo metu jau beveik visose sveikatos istaigose veikia bent keletas e. sveikatos modulių, daug kur - elektroninė registracija pas gydytoją, kai kurie pacientų sveikatos istorijos įrašai pildoma elektroniniu būdu. Kuriamos vis sudètingesnès naujos e. sveikatos paslaugos. Pagrindiniai e. sveikatos sistemos naudotojai yra sveikatos priežiūros ịstaigų darbuotojai, gyventojai, sprendimų prièmèjai, informacinių technologijų firmų darbuotojai, viešojo administravimo institucijos ir kt. Tačiau pagrindiniai naudotojai, kuriems tarnauja visa sveikatos sistema, yra gyventojai.

Lietuvos Respublikos sveikatos apsaugos ministro ịsakymas. Valstybès žinios. 2007, Nr. 108-4430.

Lietuvos Respublikos sveikatos apsaugos ministro ịsakymas. Valstybès žinios. 2010, Nr. 21-1015. 
Norint kryptingai tobulinti e. sveikatos sistemą ir padidinti gyventojų naudojimąsi e. sveikatos paslaugomis, reikia turèti specifinių žinių apie sistemos trūkumus. Geriausiai veikiančios e. sveikatos prieinamumą rodo naudotojai ir jų noras naudotis sukurtomis sistemomis. Taigi sužinojus, kokị (kokius) e. sveikatos paslaugų naudotojo portretą pagal socialines demografines charakteristikas tenkina dabartine e. sveikatos sistema, t. y. kokie gyventojai, atsižvelgiant ị jų socialinius-demografinius rodiklius, naudojasi arba labiau linkę naudotis e. sveikatos paslaugomis, galima gauti informacijos apie veikiančios sistemos trūkumus, ieškoti sprendimų, kaip pritraukti kitus naudotojus. Naudotojo portretas atskleidžia būdingus tam tikros tikslinės naudotojų grupès bruožus ir leidžia prognozuoti kitų naudotojų elgesị ateityje. Naudotojo portretas yra viena iš pripažintų e. paslaugos tinkamumo gerinimo priemonių ${ }^{3}$.

Straipsnyje pateikto tyrimo tikslas yra nustatyti e. sveikatos paslaugų Lietuvoje naudotojo portretą išsiaiškinant, kokị e. sveikatos paslaugų naudotojo portretą tenkina dabartinè e. sveikatos sistema Lietuvoje.

\section{Mokslinès literatūros apžvalga}

Literatūroje randamos įvairios "naudotojo portreto" (angl. user profile) sąvokos, tokios kaip: persona (angl. persona), personos aprašymas (angl. persona description) arba vartotojo aprašymas (angl. user description). Dažnai autoriai šias sąvokas vartoja kaip sinonimus, tačiau jos nèra tapačios. „Persona (angl. persona) - tai detalus ísivaizduojamo žmogaus aprašymas, pateikiant gerai žinomus, tiksliai apibrèžtus duomenis apie realius žmones ${ }^{\mathrm{s}_{4}}$.

Kitaip tariant, „persona yra teorinis stereotipiškas naudotojo apibūdinimas,

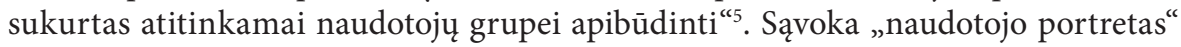
(angl. user profile) dažnai literatūroje klaidingai vartojama kaip „personos“ sinonimas. Neretai autoriai naudotojo portretą (angl. user profile) pateikia kaip trumpą, daugiausiai demografinių-socialinių savybių aprašymą, todèl toks naudotojo portretas negali būti tapatinamas su „personos“ sąvoka ${ }^{6}$. Naudotojo portretas arba aprašymas yra dalis detalaus personos aprašymo, todèl dažnai mokslininkai šiuos du metodus derina tarpusavyje. Portreto sukūrimas yra pirmas ir svarbus etapas siekiant nustatyti, kokie asmenys turètų būti įtraukti ị paslaugos ar produkto projektavimą ${ }^{7}, 8$.

Pruitt, J.; Adlin, T. The Persona Lifecycle: Keeping People in Mind Throughout Product Design. Morgan Kaufmann Publishers, San Francisco, CA, 2006.

Ibid.

Dayton, D. Audiences involved, imagined, and invoked: trends in user-centered interactive information design. In Professional Communication Conference. IPCC 2003, IEEE International, Piscataway, NJ, 2003. Cooper, A.; Reimann, R.; Cronin, D. About Face, 3rd ed., The Essentials of Interaction Design. Wiley Publishing, Inc., Indianapolis, IN, 2007.

7 LeRouge, C., et al. User profiles and personas in the design and development of consumer health technologies. Int. J. Med. Inform. (2011), doi:10.1016/j.ijmedinf.2011.03.006

8 Karapanos, E.; Martens, J. B. Characterizing the Diversity in Users' Perceptions Human-Computer Interaction - INTERACT 2007. The Netherlands, Eindhoven, Eindhoven University of Technology, LNCS 4662, Part I, 2007, p. 515-518. 
Siekiant suprasti, kas yra „naudotojo portretas“, svarbu susipažinti su dar viena sąvoka - „i naudotoją (vartotoją) nukreiptas modelis" User-centered design (UCD) tai plati sąvoka, vartojama apibūdinti projektavimo procesus, kuriuose galutinis naudotojas (vartotojas) turi įtakos, kokią formą ar pavidalą igaus tam tikras produktas9. Dažniausiai produktas yra susiję su informacinemis komunikacijos techno$\operatorname{logijomis}{ }^{10}$, pvz., elektroninemis sveikatos paslaugomis. Itraukti naudotojus ị $U C D$ galima ịvairiais būdais, tačiau svarbu yra tai, kad vienu ar kitu būdu naudotojai yra itraukti ir dalyvauja tam tikro produkto projektavimo procese ${ }^{11}$. Naudotojo portretas yra vienas iš $U C D$ metodų. Šis metodas atsirado didejant poreikiui analizuoti bei konsoliduoti didelị informacijos apie naudotojus kiekị, gautą interviu metu, iš apsilankymų internetinèse svetainėse, atsakinejant ị naudotojams pateiktus klausimynus ir kitų naudotojų tyrimo formų. Naudotojo portretas kaip UCD metodas pradètas taikyti 1980-ųjų pradžioje inžinerijoje. Iki 1998 metų nebuvo vienos „naudotojo portreto" koncepcijos, skirtingose disciplinose ji buvo nevienoda ${ }^{12}$.

J. T. Hackos ir J. C. Redish knygoje "User and Task Analysis for Interface Design“ (1998) detaliai aprašo naudotojo portreto koncepciją, pateikia metodologiją, kaip reikia kurti naudotojo portretą ir kur jis yra naudojamas. Paprastai naudotojo portretas yra tiksli ir glausta surinktų duomenų apie realius naudotojus santrauka. Skirtingai nei „personos" aprašyme, naudotojo portrete nèra pasakojama apie naudotojų patirtị, kaip naudotojas galvoja, jaučiasi ir elgiasi, taip pat nèra išgalvotų portreto detalių siekiant sukurti kuo realesnį atvaizdą. Kai kuriais atvejais jis gali būti beasmenis, abstraktus aprašomų demografinių-socialinių rodiklių rinkinys ${ }^{13}$.

"Naudotojo portreto" ir "personos" metodai taikomi ir e. sveikatos paslaugu kokybei gerinti. Pavyzdžiui, 2006 metais Jungtinių Amerikos Valstijų mokslininkai, atlikę tyrimą, kas naudojasi e. sveikatos paslauga - pacientų portalu, nustaté, kad paslauga daugiau naudojasi jaunesni, labiau pasiturintys bei retai sergantys pacientai. Mokslininkai priejjo prie išvados, kad reikia tobulinti portalą, išsiaiškinant, kokios kliūtys trukdo pacientų portalu naudotis tiems pacientams, kurie iš to gali gauti daugiausia naudos (t. y. dažniau sergantys, vyresni, mažiau pasiturintys gyventojai $)^{14} .2007$ metais atliktas Europos piliečių naudojimosi e. sveikatos paslaugomis septynių šalių tyrimas atskleidè Norvegijos, Danijos, Vokietijos, Graikijos, Lenkijos, Portugalijos bei Latvijos e. sveikatos paslaugų naudotojų skirtumus ir panašumus. Šiame tyrime taip pat buvo nustatyta, kad interneto naudojimas ieškant su sveikata susijusios informacijos neturi itakos naudojimuisi kitomis e. sveikatos paslaugomis, tačiau naršymas internete ieškant informacijos apie sveikatą papildo,

Abras, C.; Maloney-Krichmar, D.; Preece, J. User-Centered Design. In Bainbridge, W. Encyclopedia of Human-Computer Interaction. Thousand Oaks: Sage Publications, 2004.

10 Pruitt, J.; Adlin, T. The Persona Lifecycle: Keeping People in Mind Throughout Product Design, Morgan Kaufmann Publishers, San Francisco, CA, 2006

11 Abras, C.; Maloney-Krichmar, D.; Preece, J., op. cit.

12 Pruitt, J.; Adlin, T. The Persona Lifecycle: Keeping People in Mind Throughout Product Design. Morgan Kaufmann Publishers, San Francisco, CA, 2006.

$13 \quad$ Ibid.

14 Weingart, S. N.; Rind, D.; Tofias, Z; Sands, D. Z. Who Uses the Patient Internet Portal? The PatientSite Experience. Journal of the American Medical Informatics Association. 2006, 139 (1): 91-95. 
o ne pakeičia kitas e. sveikatos paslaugas ${ }^{15} .2012$ metais mokslininkai pademonstravo, kaip šie metodai gali būti pritaikyti projektuojant ir plètojant prietaisus, susijusius su e. sveikata senstančiai populiacijai, taip pat asmenims, turintiems specifinių poreikių ar sergantiems cukriniu diabetu ${ }^{16}$. Kiti mokslininkai irgi priejjo panašias išvadas ${ }^{17}$.

Lietuvos teisès aktuose e. sveikata apibrèžiama kaip „<...> sveikatos apsaugos, medicinos informatikos ir administracinès veiklos visuma, užtikrinama diegiant informacines ir ryšių technologijas, organizacines veiklos naujoves ir naujus igūdžius ir skirta sveikatinimo (asmens, visuomenès, farmacijos) paslaugoms tobulinti operatyviai pateikiant išsamią veiklai reikalingą informaciją ${ }^{18}$. Tolesniems tyrimams apsibrěšime, kad e. sveikatos paslaugų naudotojas yra asmuo, kuris sąmoningai ir tikslingai siekia gauti sveikatos priežiūros paslaugas, teikiamas elektroninèmis priemonemis, per atstumą, o e. sveikatos paslauga - tai e. sveikatos igyvendinimo priemone, pvz., išankstinè registracija internetu, elektroninis receptas ar kitas modulis. Šiuo metu Lietuvoje yra igyvendinama „Lietuvos e. sveikatos 2007-2015 metu plètros strategija“" (toliau - Strategija), kurioje nurodoma, jog nuo 2014 m. pradžios prasidejo paskutinis Strategijos igyvendinimo etapas ${ }^{19}$.

E. sveikata yra pakankamai jauna sritis Lietuvoje. Tyrimų, susijusių su e. sveikatos paslaugų naudotojų aprašymu, iki 2013 m. atlikta vos keletas. Dauguma jų apima siaurą naudotojų grupę, tam tikros ligoninès pacientus, aprašomi tik keli socialiniai rodikliai, tokie kaip lytis, amžius. 2009 metais atliktas „Elektroninès sveikatos paslaugu ir jų poreikio vertinimo“ tyrimas Klaipeddoje. Tyrime dalyvavo Klaipèdos universitetineje ligonineje besilankantys pacientai. Tyrimo metu nustatyta, jog apie pusė respondentų nežinojo apie išankstinę registraciją pas gydytoją internetu, šios galimybès pageidavo didžioji dauguma apklaustųjų ${ }^{20} .2010$ metais atliktas „Pacientų nuomonès apie informacinių technologijų panaudojimą Vilniaus miesto Centro ir Šeškinès poliklinikose pagal pacientų amžių“ tyrimas. Nustatyta, kad e. sveikatos paslauga - išankstine registracija internetu daugiau naudojasi jaunesnio amžiaus gyventojai ${ }^{21}$.

Taigi, siekiant, kad e. sveikatos paslaugos Lietuvoje sèkmingai plèstųsi ir tobulètų, pirmiausia būtina išsiaiškinti, kokị e. sveikatos paslaugų „naudotojo portretą“" tenkina dabartinè e. sveikatos sistema Lietuvoje bei nustatyti tipinio e. sveikatos paslaugų „naudotojo portretą“

15 Andreassen, H. K., et al. European citizens' use of E-health services: A study of seven countries. BMC Public Health, 2007, 7: 53.

16 LeRouge, C., et al., supra note 7.

17 van Velsen, L., et al. Personas: The Linking Pin in Holistic Design for eHealth. eTELEMED 2012: The Fourth International Conference on eHealth, Telemedicine, and Social Medicine, 2012.

18 Lietuvos Respublikos sveikatos apsaugos ministro ịsakymas, supra note 2.

19 Lietuvos Respublikos sveikatos apsaugos ministro įsakymas, supra note 1.

20 Stašys, R. Elektroninès sveikatos paslaugos ir jų poreikio vertinimas. Verslas, vadyba ir studijos. 2009, p. 246-260.

${ }^{21}$ Kairys, J., et al. Pacientų nuomonè apie informacinių technologijų panaudojimą Vilniaus miesto Centro ir Šeškinès poliklinikose pagal pacientų amžių. Medicinos teorija ir praktika. 2011, 11(1): 5564. ISSN, 1392-1312. 


\section{Tyrimo metodai ir duomenys}

Siekiant nustatyti e. sveikatos paslaugų naudotojo portretą Lietuvoje, tyrimo metu apklausti gyventojai, kurie žino ir naudoja e. sveikatos paslaugas Lietuvoje. Tyrimui panaudoti igyvendinant projektą „E-sveikatos plètros integruotos transformacijos: suinteresuotųjų pusių tinklo perspektyva" VP1-3.1-ŠMM-07-K-02-029/2013 atlikto kiekybinio gyventojų apklausos tyrimo empiriniai duomenys.

Gyventojų apklausa vyko interviu metodu respondentų namuose. Ją 2013 metais atliko visuomenès nuomonès ir rinkos tyrimų centras „Vilmorus“. Tyrime dalyvavo vienas tūkstantis Lietuvos gyventojų iš įvairių miestų ir rajonų (žr. 1 pav.). Tyrimo objektas buvo 18 metų ir vyresni gyventojai. Respondentų atranka buvo parengta taip, kad kiekvienas Lietuvos gyventojas turètų vienodą tikimybę būti apklaustas, taikyta daugiapakopé, tikimybinè atranka.

Tyrime dalyvavusių respondentų 45,3 proc. buvo vyrai bei 54,7 proc. - moterys. Gyventojų amžius svyravo nuo 18 iki 90 metų, jų amžiaus vidurkis buvo 47,21 $( \pm 18,29)$ metai. Vidutinè suma tenkanti vienam šeimos nariui per ménesi buvo $890,88( \pm 548,43)$ Lt. Didžioji dalis respondentų turèjo (spec.) vidurinijji ar aukštesnịji išsilavinimą (60,9 proc.), beveik trečdalis - aukštąji ( 27,3 proc.), mažiausia dalis buvo neturinčių vidurinio išsilavinimo (11,8 proc.). 46,4 proc. respondentų gyveno didmiesčiuose bei likę 53,6 proc. - kituose miestuose ir kaimuose.

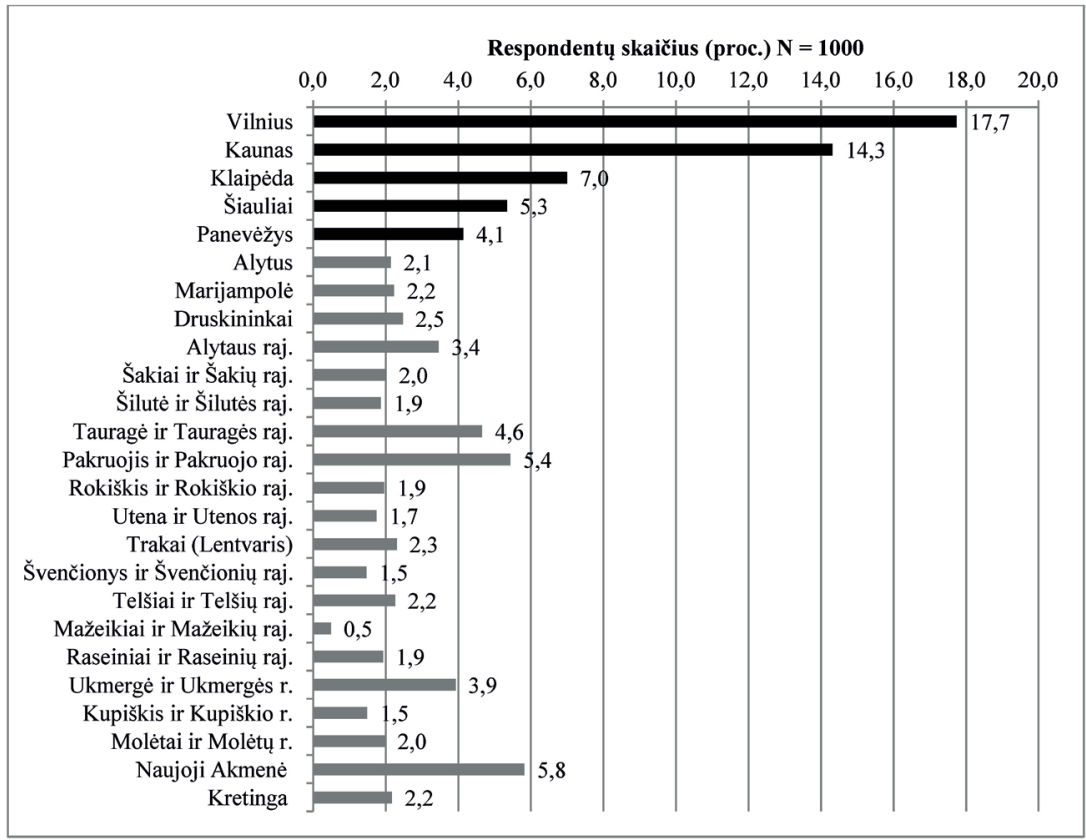

1 pav. Gyventojų, dalyvavusių apklausoje, pasiskirstymas pagal gyvenamąją vietą, proc. 
Taip pat norint išsiaiškinti, koks yra dabartinès e. sveikatos paslaugų žinomumo ir naudojimo lygis tarp Lietuvos gyventojų, kurie dažnai naudojasi sveikatos priežiūros paslaugomis, buvo nustatytas dažnai besinaudojančio sveikatos priežiūros paslaugomis gyventojo portretas. Dažnai besinaudojantys sveikatos priežiūros paslaugomis laikyti tie gyventojai, kurie per pastaruosius dvejus metus jomis naudojosi 6 ir daugiau kartų. Išskirti „portretai“ buvo lyginami tarpusavyje.

Analizei atlikti taikytas antrinès kiekybinių duomenų analizès metodas. Statistine duomenų analizé atlikta naudojant statistinių duomenų apdorojimo paketą „SPSS“ (17 versija), taip pat „WinPepi“ bei Microsoft Excel 2010 programas. Taikyta aprašomoji statistika, kategorinių-nominalinių duomenų analizei naudotas chi kvadrato $(\chi 2)$ testas ir tikslusis Fišerio (Fisher's) testas. Kruskalio ir Walliso testas taikytas kategoriniams-ranginiams duomenims palyginti. Duomenų skirtumas laikytas statistiškai reikšmingu, kai $\mathrm{p} \leq 0,05$.

Naudojimasis paslaugomis analizuotas atsižvelgiant ị gyventojų socialinius-demografinius rodiklius, t. y. lytị, gyvenamąją vietą, amžių, išsilavinimą, užimtumą, šeiminę padètị bei šeimos dydị ir pajamas. Taip pat atsižvelgiant ị pacientų naudojimosi sveikatos priežiūros paslaugomis dažnį bei tai, kokiose asmens sveikatos priežiūros įstaigose gyventojai lankosi dažniau - privačiose ar valstybinėse.

Empirinių duomenų analizè

Analizuotos 14 e. sveikatos paslaugų, kurios šiuo metu yra ịgyvendintos arba iš dalies ịgyvendintos Lietuvoje (žr. 1 lentelę).

1 lentelè. E. sveikatos paslaugas žinančių ir jas naudojančių gyventojų dalis

\begin{tabular}{|c|c|c|c|c|c|}
\hline \multirow[t]{2}{*}{$\begin{array}{l}\text { Eil. } \\
\text { Nr. }\end{array}$} & \multirow[t]{2}{*}{ E. sveikatos paslauga } & \multicolumn{2}{|c|}{$\begin{array}{l}\text { Gyventojų, } \\
\text { žinančių pa- } \\
\text { slaugą, dalis }\end{array}$} & \multicolumn{2}{|c|}{$\begin{array}{l}\text { Gyventojų, } \\
\text { naudojančių } \\
\text { paslaugą, } \\
\text { dalis* }^{*}\end{array}$} \\
\hline & & $\mathrm{N}$ & $\%$ & $\mathrm{~N}$ & $\%$ \\
\hline 1. & Pacientų registracija pas gydytoją internetu & 660 & 66,0 & 297 & 45,0 \\
\hline 2. & $\begin{array}{l}\text { Pacientas gauna priminimą apie vizitą pas gydytoją } \\
\text { SMS žinute ar el. paštu }\end{array}$ & 353 & 35,3 & 167 & 47,4 \\
\hline 3. & $\begin{array}{l}\text { Gydantis gydytojas elektroniniu būdu registruoja pacien- } \\
\text { to siuntimą konsultuoti, atlikti tyrimus, gydytis pas savo } \\
\text { îstaigos specialistus }\end{array}$ & 334 & 33,4 & 157 & 47,0 \\
\hline 4. & $\begin{array}{l}\text { Gydantis gydytojas pildo ir išsiunčia elektroniniu būdu } \\
\text { paciento siuntimą konsultuoti, atlikti tyrimus, gydytis } \mathfrak{i} \\
\text { kitą gydymo îstaigą }\end{array}$ & 273 & 27,3 & 93 & 34,1 \\
\hline 5. & $\begin{array}{l}\text { Gydantis gydytojas / slaugytoja el. būdu tvarko medicini- } \\
\text { nę informaciją apie paciento stacionarinị gydymą (anam- } \\
\text { nezè, nusiskundimai ir kt.) }\end{array}$ & 237 & 23,7 & 76 & 32,2 \\
\hline 6. & $\begin{array}{l}\text { Gydantis gydytojas / slaugytoja el. būdu užsako laborato- } \\
\text { rijos tyrimus ir/ ar gauna rezultatus }\end{array}$ & 283 & 28,3 & 140 & 49,5 \\
\hline
\end{tabular}




\begin{tabular}{|c|c|c|c|c|c|}
\hline 7. & $\begin{array}{l}\text { Gydantis gydytojas / slaugytoja el. būdu saugo ir / ar } \\
\text { peržiūri skaitmeninius vaizdus (radiologinių ir/ar instru- } \\
\text { mentinių tyrimų rezultatus) }\end{array}$ & 289 & 28,9 & 147 & 50,9 \\
\hline 8. & Gydantis gydytojas pildo receptus el. būdu & 129 & 12,9 & 21 & 16,3 \\
\hline 9. & $\begin{array}{l}\text { Gydantis gydytojas el. būdu planuoja hospitalizavimą } \\
\text { (chirurginiam ar terapiniam gydymui ir kt.) }\end{array}$ & 152 & 15,2 & 36 & 23,7 \\
\hline 10. & $\begin{array}{l}\text { Gydantis gydytojas / slaugytoja el. būdu planuoja imuno- } \\
\text { profilaktiką (skiepijimus) ir/ar jų apskaitą }\end{array}$ & 114 & 11,4 & 19 & 16,7 \\
\hline 11. & $\begin{array}{l}\text { Gydantis gydytojas naudojasi telemedicina (telemonito- } \\
\text { ringas, telepaslaugos ir kt.) }\end{array}$ & 108 & 10,8 & 27 & 25,0 \\
\hline 12. & Gydantis gydytojas el. būdu stebi / seka nèštumo eigą & 107 & 10,7 & 17 & 15,9 \\
\hline 13. & $\begin{array}{l}\text { Pacientas turi galimybę pasižiūrèti savo elektroninę ligos } \\
\text { istoriją }\end{array}$ & 137 & 13,7 & 24 & 17,5 \\
\hline 14. & Gydantis gydytojas pildo nedarbingumo lapelị el. būdu & 428 & 42,8 & 191 & 44,6 \\
\hline
\end{tabular}

*Apskaičiuota nuo paslaugą žinančių gyventojų.

Siekiant kuo tiksliau nustatyti e. sveikatos paslaugų naudotojo portretą analizuojant duomenis buvo pasirinktos trys Lietuvos gyventojams geriausiai žinomos paslaugos: pacientų registracija pas gydytoją internetu $(\mathrm{N}=660)$, gydantis gydytojas pildo nedarbingumo lapelị el. būdu $(\mathrm{N}=428)$ bei pacientas gauna priminimą apie vizitą pas gydytoją SMS žinute ar el. paštu $(\mathrm{N}=353)$. Šiomis paslaugomis naudojasi atitinkamai 45,0 proc. $(\mathrm{N}=297), 44,6$ proc. $(\mathrm{N}=191)$ bei 47,4 proc. $(\mathrm{N}=167)$ e. sveikatos paslaugas žinančių gyventojų.

Tyrimas parodè, kad e. sveikatos paslaugas geriau žino moterys (nuo 57,9 proc. iki 60,8 proc.) nei vyrai (nuo 39,2 proc. iki 42,1 proc.) (priklausomai nuo paslaugos $\mathrm{p}=0,004 ; \mathrm{p}=0,007$ ). Nuo 33,3 proc. iki 41,4 proc. respondentų, naudojančių e. sveikatos paslaugas, yra vyrai, nuo 58,6 proc. iki 66,7 proc. - moterys (priklausomai nuo paslaugos $\mathrm{p}=0,053 ; \mathrm{p}=0,741 ; \mathrm{p}=0,939$ ), tačiau statistiškai patikimas skirtumas tarp lyties ir naudojimosi e. sveikatos paslaugomis nenustatytas.

E. sveikatos paslaugų regioninė skverbtis. Neturètume stebètis, kad e. sveikatos regioninè skverbtis kol kas siekia tik didmiesčius. Apie e. sveikatos paslaugas tiek daugiau žino (nuo 55,4 proc. iki 59,9 proc.; $\mathrm{p} \leq$ 0,001), tiek daugiau naudoja (nuo 61,3 proc. iki 67,3 proc.; priklausomai nuo paslaugos $\mathrm{p}=0,007 ; \mathrm{p}=0,012$ ) didmiesčiu gyventojai. Nuo 40,1 proc. iki 44,6 proc. respondentų, žinančių e. sveikatos paslaugas, gyvena kituose miestuose ar kaimuose, tokių gyventojų tarp respondentų, naudojančių e. sveikatos paslaugas, yra nuo 32,7 proc. iki 38,7 proc. (žr. 2 pav.) 


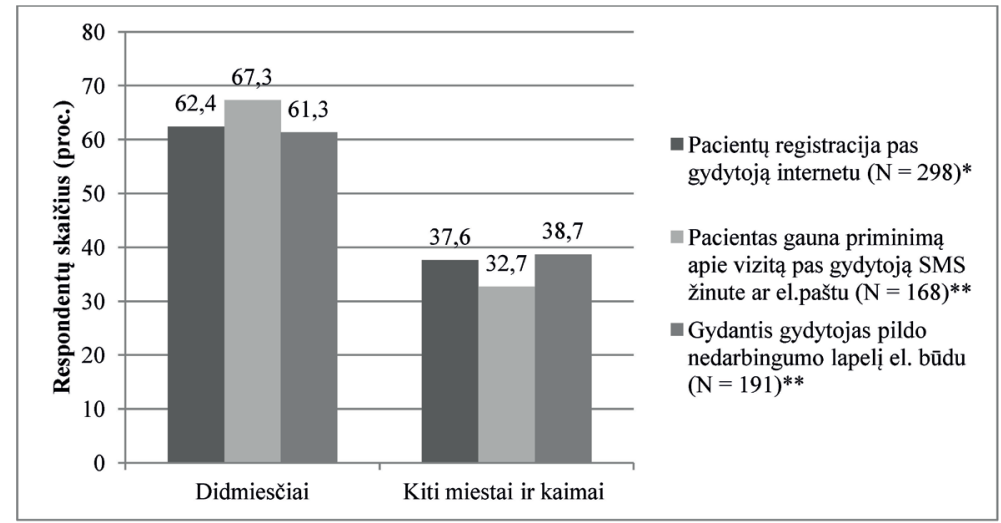

${ }^{*} \mathrm{p}=0,007 ;{ }^{* *} \mathrm{p}=0,012$;

2 pav. Gyventojų, naudojančių e. sveikatos paslaugas, pasiskirstymas pagal gyvenamąją vietą

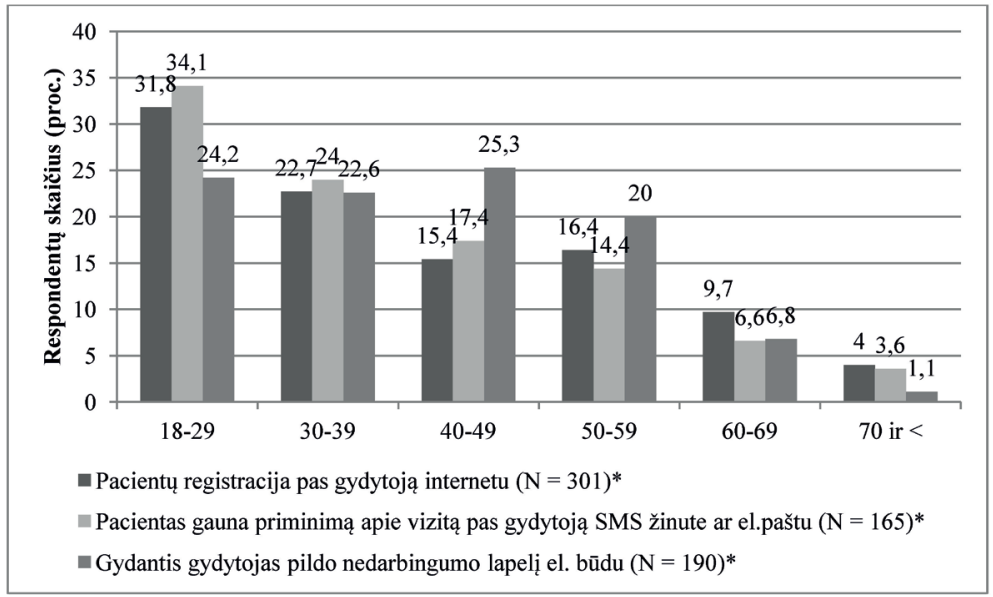

${ }^{\star} \mathrm{p} \leq 0,001$

3 pav. Gyventojų, naudojančių e. sveikatos paslaugas, pasiskirstymas pagal amžių

Amžius ir e. sveikatos paslaugų žinomumas E. sveikatos paslaugų žinojimas $(\mathrm{p} \leq 0,001)$ ir naudojimasis $(\mathrm{p} \leq 0,001)$ jomis priklauso nuo amžiaus, šias paslaugas daugiau žino ir jas naudoja jaunesnio amžiaus gyventojai. Respondentai iki 29 metų sudarè ketvirtadali paslaugas žinančių gyventojų (21,3 proc. - 26,6 proc.), 30-39 metų amžiaus grupé sudarè nuo 17,2 proc. iki 20,7 proc. tokių gyventojų, 40-49 metų amžiaus grupė nuo 19,4 proc. iki 24,1 proc., 50-59 - nuo 15,0 proc. iki 18,5 proc., 60-69 - nuo 11,0 proc. iki 12,1 proc., 70 ir vyresni - nuo 4,9 proc. iki 
9,2 proc. Respondentai iki 29 metų sudarè trečdalị paslaugomis besinaudojančių gyventojų (24,2 proc. - 34,1 proc.), 30-39 metų amžiaus grupé sudarè nuo 22,6 proc. iki 24,0 proc. tokių gyventojų, 40-49 metų amžiaus grupé - nuo 15,4 proc. iki 25,3 proc., $50-59$ - nuo 14,4 proc. iki 20,0 proc., $60-69$ - nuo 6,6 proc. iki 9,7 proc., 70 ir vyresni - nuo 1,1 proc. iki 4,0 proc. (žr. 3 pav.).

Išsilavinimas ir e. sveikatos paslaugų žinomumas. E. sveikatos paslaugų žinojimas $(\mathrm{p} \leq 0,001)$ ir naudojimasis jomis (priklausomai nuo paslaugos $\mathrm{p}=0,001$; $\mathrm{p}=0,015 ; \mathrm{p}=0,012)$ priklauso nuo gyventojų išsilavinimo. Kuo aukštesnis gyventoju išsilavinimas, tuo daugiau gyventojų žino apie e. sveikatos paslaugas ir jomis naudojasi. Paslaugas žino nuo 49,5 proc. iki 79,1 proc. aukštąji išsilavinimą turinčiu gyventojų, nuo 33,6 proc. iki 66,7 proc. turinčių specialųji vidurinị ar aukštesnịji išsilavinimą, nuo 12,0 proc. iki 33,1 proc. nebaigusių vidurinio išsilavinimo. Paslaugomis naudojasi nuo 51,6 proc. iki 57,5 proc. aukštąji išsilavinimą turinčių gyventojų, nuo 40,2 proc. iki 42,7 proc. turinčių specialųjj vidurinị ar aukštesnijji išsilavinimą, nuo 18,8 proc. $(\mathrm{N}=3)$ iki 53,3 proc. $(\mathrm{N}=8)$ nebaigusių vidurinio išsilavinimo (žr. 4 pav.).

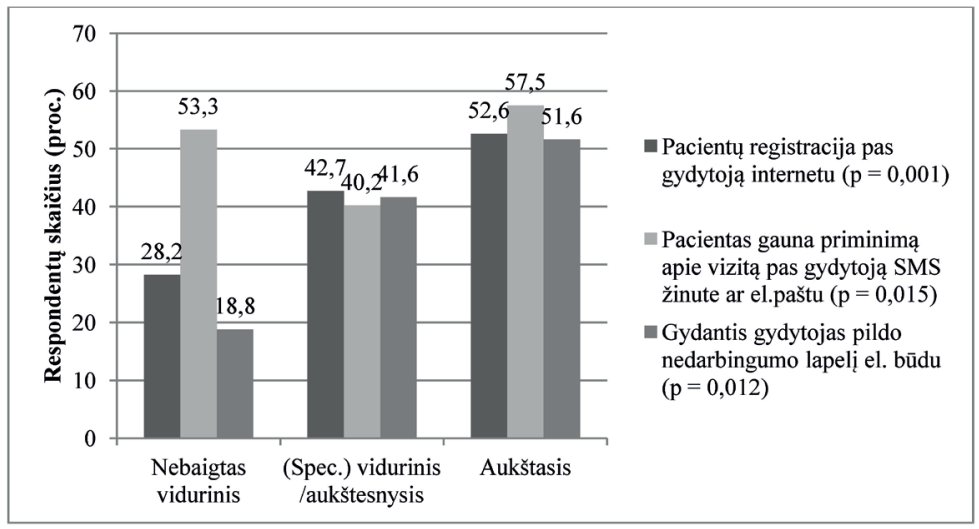

4 pav. Gyventojų, naudojančių e. sveikatos paslaugas, pasiskirstymas pagal išsilavinimą

Užimtumas ir e. sveikatos paslaugų žinomumas Skirtingo užimtumo gyventojai e. sveikatos paslaugas žino ( $\mathrm{p} \leq 0,001)$ ir jomis naudojasi $(\mathrm{p} \leq 0,001)$ nevienodai. Pensinio amžiaus ar neigalūs gyventojai šias paslaugas žino (nuo 23,5 proc. iki 51,6 proc.) mažiausiai. Bedarbių, žinančių e. sveikatos paslaugas, dalis svyruoja nuo 28,7 proc. iki 57,4 proc. Geriausiai paslaugas žino moksleiviai ir studentai (nuo 33,8 proc. iki 78,5 proc.), darbininkai ir specialistai (nuo 39,5 proc. iki 74,9 proc.), verslininkai ir vadovai (nuo 44,4 proc. iki 74,4 proc.). Mažiausiai e. sveikatos paslaugomis naudojasi pensinio amžiaus ar neigalūs gyventojai (nuo 16,9 proc. iki 29,1 proc.). Bedarbių, besinaudojančių paslaugomis, yra nuo 50,6 proc. iki 60,0 proc. Moksleivių ir studentų, besinaudojančių e. sveikatos paslaugomis, dalis svyruoja nuo 27,3 proc. iki 66,7 proc., darbininkų ir specialistų - nuo 46,4 proc. iki 53,4 proc., verslininkų ir vadovų - nuo 39,2 proc. iki 55,0 proc. 
Pastebèta, kad didelè dalis bedarbių žino ir naudojasi e. sveikatos paslaugomis. Nustatyta, kad didžioji dalis tyrime dalyvavusių bedarbių, žinančių e. sveikatos paslaugas, buvo jauni žmonès, didžiausią dalị sudare 18-39 metų amžiaus grupés gyventojai (nuo 52,8 proc. iki 55,0 proc.). Taip pat dauguma šios grupès gyventoju turejjo specialųji vidurinị ar aukštesnịji išsilavinimą (nuo 37,8 proc. iki 61,5 proc.) ir aukštąji išsilavinimą (nuo 29,5 proc. iki 57,1 proc.) bei gyveno didmiesčiuose (nuo 43,4 proc. iki 53,8 proc.). Taip pat dauguma tyrime dalyvavusių bedarbių, kurie naudojasi e. sveikatos paslaugomis, buvo jauni žmonès, didžiausią dalị sudarè 18-29 metų amžiaus grupès gyventojai (nuo 34,5 proc. 45,8 proc.). Dauguma bedarbių, naudojančių e. sveikatos paslaugas, turèjo specialųji vidurinị ar aukštesnịji išsilavinimą (nuo 44,4 proc. iki 72,4 proc.) ir aukštąji išsilavinimą (nuo 24,1 proc. 48,0 iki proc.) bei gyveno didmiesčiuose (nuo 42,9 proc. iki 69,6 proc.).

Šeiminè padètis ir e. sveikatos paslaugu žinomumas. E. sveikatos paslaugu žinojimas priklauso nuo gyventojų šeiminès padèties (priklausomai nuo paslaugos $\mathrm{p} \leq 0,001 ; \mathrm{p}=0,005)$. E. sveikatos paslaugas žino nuo 38,2 proc. iki 70,2 proc. santuokoje gyvenančių respondentų, nevedusių ar netekejusių - nuo 38,9 proc. iki 69,9 proc., gyvenančiu neregistruotoje santuokoje - nuo 35,8 proc. iki 67,6 proc., išsiskyrusių - nuo 31,9 proc. iki 62,1 proc. bei našlių - nuo 19,8 proc. iki 46,3 proc. Naudojimasis e. sveikatos paslaugomis ne visada priklauso nuo šeiminès padèties. Nustatyta, kad iš trijų analizuotų paslaugų tik viena e. sveikatos paslauga (pacientų registracija pas gydytoją internetu) priklauso nuo šeiminès padèties $(\mathrm{p}=0,007)$. Šia paslauga naudojasi 53,0 proc. nevedusių ar netekejjusių, 47,0 proc. santuokoje gyvenančių, 39,7 proc. išsiskyrusių, 31,1 proc. neregistruotoje santuokoje gyvenančių bei 30,4 proc. našlių respondentų. Matyt, gyventojai šeimoje dalinasi informacija apie sveikatos priežiūros paslaugas ir tai svarbu ịvertinti inovacijų diegimo procese.

E. sveikatos paslaugų žinojimas priklauso nuo šeimos, kurioje gyvena respondentas, dydžio, t. y. nuo vaikų iki 17 metų, gyvenančių respondento namų ūkyje, skaičiaus. Didesnèse šeimose gyvenantys respondentai e. sveikatos paslaugas žino geriau nei gyvenantieji mažesnèse (priklausomai nuo paslaugos $\mathrm{p}=0,003$; $\mathrm{p} \leq 0,001)$. Namų ūkių, kuriuose nẻra vaikų iki 17 metų, e. sveikatos paslaugas žino nuo 32,5 proc. iki 63,7 proc. gyventojų, kurių namų ūkyje gyvena vienas vaikas iki 17 metu - nuo 41,8 proc. iki 71,3 proc., du vaikai - nuo 39,6 proc. iki 71,7 proc. bei 3 ir daugiau vaikų - nuo 38,9 proc. iki 77,8 proc. Naudojimasis e. sveikatos paslaugomis ne visada priklauso nuo šeimos dydžio. Nustatyta, kad iš trijų analizuotų paslaugų tik viena e. sveikatos paslauga (pacientų registracija pas gydytoją internetu) priklauso nuo šeimos dydžio ( $\mathrm{p} \leq 0,001)$. Šia paslauga daugiausia naudojasi tie gyventojai, kurių namų ūkyje gyvena vienas ir daugiau vaikų iki 17 metų. E. sveikatos paslauga naudojasi 40,2 proc. gyventojų, kurių namų ūkyje nèra vaikų iki 17 metų, 58,3 proc. gyventojų, kurių namų ūkyje gyvena vienas vaikas iki 17 metų, 53,9 proc. gyventojų, kurių namų ūkyje gyvena du vaikai iki 17 metų, bei 30,8 proc. gyventojų, kurių namų ūkyje gyvena 3 ir daugiau vaikų iki 17 metų.

Pajamos ir e. sveikatos paslaugų žinomumas E. sveikatos paslaugų žinojimas priklauso nuo gyventojų pajamų dydžio, t. y. nuo sumos, tenkančios vienam šeimos 
nariui per mėnesĭ, dydžio. Didesnes pajamas gaunantys gyventojai paslaugas žino geriau nei gaunantieji mažesnes (priklausomai nuo paslaugos $\mathrm{p}=0,001 ; \mathrm{p}=0,030$; $\mathrm{p} \leq 0,001$ ). Gyventojų dalis, žinančių e. sveikatos paslaugas, kurių vienam šeimos nariui per ménesį tenka iki $400 \mathrm{Lt}$, svyruoja nuo 34,7 proc. iki 60,3 proc. Tokiu gyventojų, kurių vienam šeimos nariui per mėneși tenka nuo $401 \mathrm{Lt}$ iki $600 \mathrm{Lt}$, dalis svyruoja nuo 30,9 proc. iki 64,0 proc., $601-800 \mathrm{Lt}$ - nuo 25,9 proc. iki 55,1 proc., 801-1000 Lt - nuo 38,3 proc. iki 64,2 proc. bei $1001 \mathrm{Lt}$ ir daugiau - nuo 40,1 proc. iki 77,5 proc. Naudojimasis e. sveikatos paslaugomis ne visada priklauso nuo pajamu dydžio. Nustatyta, kad iš trijų analizuotų paslaugų tik viena e. sveikatos paslauga (gydantis gydytojas pildo nedarbingumo lapelị el. būdu) priklauso nuo pajamų dydžio $(p=0,026)$, šia paslauga daugiau naudojasi didesnes pajamas gaunantys gyventojai. E. sveikatos paslauga naudojasi 42,6 proc. gyventojų, kurių vienam šeimos nariui per ménesį tenka iki $400 \mathrm{Lt}, 49,2$ proc. - nuo $401 \mathrm{Lt}$ iki $600 \mathrm{Lt}, 32,8$ proc. nuo $601 \mathrm{Lt}$ iki $800 \mathrm{Lt}, 35,9$ proc. - nuo $801 \mathrm{Lt}$ iki $1000 \mathrm{Lt}$ bei 61,0 proc. - $1001 \mathrm{Lt}$ ir daugiau.

Naudojimasis sveikatos priežiūros paslaugomis ir e. sveikatos paslaugų žinomumas. E. sveikatos paslaugų žinojimas (priklausomai nuo paslaugos $p=0,010$; $\mathrm{p}=0,006 ; \mathrm{p}=0,012$ ) ir naudojimasis jomis (priklausomai nuo paslaugos $\mathrm{p} \leq 0,001$; $\mathrm{p}=0,002 ; \mathrm{p}=0,001)$ priklauso nuo naudojimosi sveikatos priežiūros paslaugomis dažnio. Gyventojai, dažnai besinaudojantys sveikatos priežiūros paslaugomis, e. sveikatos paslaugas žino geriau bei daugiau jomis naudojasi nei retai besinaudojantieji sveikatos priežiūros paslaugomis. E. sveikatos paslaugas žino nuo 30,8 proc. iki 62,1 proc. respondentų, kurie praktiškai nesinaudoja sveikatos priežiūros paslaugomis (t. y. per pastaruosius dvejus metus nesinaudojo ar naudojosi vieną kartą), 40,2-70,9 proc. - kurie naudojasi nuo 2 iki 5 kartų, 36,4-66,6 proc. - kurie naudojasi 6 kartus ir dažniau Atitinkamai e. sveikatos paslaugomis naudojasi nuo 9,7 proc. iki 17,8 proc. tų gyventojų, kurie per pastaruosius dvejus metus praktiškai nesinaudojo sveikatos priežiūros paslaugomis, nuo 22,0 proc. iki 39,1 proc. - kurie naudojosi $2-5$ kartus, nuo 19,5 proc. iki 32,2 proc. - kurie e. sveikatos paslaugomis naudojasi 6 ir daugiau kartų.

Paslaugų žinojimas (priklausomai nuo paslaugos $\mathrm{p}=0,207 ; \mathrm{p}=0,122 ; \mathrm{p}=0,880$ ) ir naudojimasis jomis (priklausomai nuo paslaugos $\mathrm{p}=0,948 ; \mathrm{p}=0,810 ; \mathrm{p}=0,730$ ) nepriklauso nuo to, kokiose ASPț, valstybinèse ar privačiose, gyventojai lankosi dažniau. Nuo 32,2 proc. iki 64,5 proc. gyventojų dažniau besilankančių privačiose ASPI, žino e. sveikatos paslaugas, jomis naudojasi nuo 46,7 proc. iki 48,6 proc. tokiu gyventojų. Nuo 38,0 proc. iki 69,0 proc. gyventojų dažniau besilankančių valstybinèse ASPI žino e. sveikatos paslaugas, jomis naudojasi nuo 46,3 proc. iki 49,6 proc. tokių gyventojų.

Dažnai sveikatos priežiūros paslaugomis besinaudojančių gyventojų charakteristika. Toliau buvo analizuojami gyventojai, kurie dažnai naudojasi sveikatos priežiūros paslaugomis, t. y. tie gyventojai, kurie teigè, kad per pastaruosius dvejus metus sveikatos priežiūros paslaugomis naudojosi 6 ir daugiau kartų. Dažnai 
besinaudojančių sveikatos priežiūros paslaugomis buvo daugiau moterų nei vyrų: 66,5 proc. tokių gyventojų buvo moterys, 33,5 proc. - vyrai. Dažnai besinaudojančių sveikatos priežiūros paslaugomis respondentų daugiau gyveno didmiesčiuose (55,1 proc.) nei kituose miestuose ar kaimuose (44,9 proc.).

Dauguma gyventojų, dažnai besinaudojančių sveikatos priežiūros paslaugomis, buvo vyresnio amžiaus. Didžioji dalis (52 proc.) tokių sveikatos priežiūros paslaugų naudotojų buvo 60 metų ir vyresni, 14,7 proc. sudare 50-59 metų respondentai, mažiausią dalį sudaro $40-49$ metų amžiaus respondentai - 9,6 proc., 10,3 proc. buvo 30-39 metų respondentai bei 13,6 proc. buvo 29 metų ir jaunesni. Specialųji vidurinijji ar aukštesnijji išsilavinimą (58,4 proc.) turintys gyventojai sudare didžiausią dažnai sveikatos priežiūros paslaugomis besinaudojančiųjų dalị. Nebaigtą vidurinị išsilavinimą turèjo 16,4 proc., aukštąji - 25,3 proc. tokių gyventojų. Analizuojant gyventojus, dažnai benaudojančius sveikatos priežiūros paslaugomis, pagal užimtumą nustatyta, kad daugiau nei pusẻ jų buvo nedirbantys pensininkai ar neigalūs žmonès (53,3 proc.), ketvirtadalị (26,4 proc.) sudare darbininkai ir specialistai, 12,1 proc. - bedarbiai, 5,1 proc. - verslininkai ir vadovai bei 3,1 proc. - moksleiviai ir studentai. Pagal šeiminę padètị šios grupès gyventojai pasiskirstè taip: pusè - 47,8 proc. buvo vedę ar ištekejjusios, 23,0 proc. - našliai (-ès), 13,2 proc. nevedę ar neištekejjusios, 11,7 proc. - išsiskyrę (-usios) ir 4,3 proc. - gyvenantys neregistruotoje santuokoje. Analizuojant šią gyventojų grupę pagal šeimos, kurioje gyvena, dydį, nustatyta, kad 78,4 proc. tokių gyventojų namų ūkyje negyveno vaikų iki 17 metų, 13,2 proc. - gyveno vienas vaikas iki 17 metų, 7,8 proc. - gyveno du vaikai bei 0,6 proc. - gyveno trys ir daugiau vaikų. Analizuojant gyventojų, dažnai benaudojančių sveikatos priežiūros paslaugomis, pasiskirstymą pagal pajamas, nustatyta, kad dauguma tokių gyventojų gavo vidutines pajamas. 7,8 proc. dažnai besinaudojančių sveikatos priežiūros paslaugomis gyventojų vienam šeimos nariui per mènesị tenka iki 400 Lt, 16,9 proc. - nuo 401 iki 600 Lt, 29,7 proc. - nuo 601 iki $800 \mathrm{Lt}$, 28,4 proc. - nuo 801 iki 1000 Lt bei 17,1 proc. - 1001 Lt ir daugiau. Šios grupes gyventojų, dažniau besilankančių valstybinèse ASPț, yra daugiau (80,6 proc.) nei besilankančių privačiose (19,4 proc.).

\section{Sveikatos paslaugų žinotojų ir naudotojų portretai}

Taigi, išrinkus dominuojančius, statistiškai patikimus demografinius-socialinius požymius, buvo nustatyta sveikatos paslaugų dviejų rūšių portretai: e. sveikatos paslaugų naudotojų portretas bei dažnai sveikatos priežiūros paslaugomis besinaudojančio gyventojo portretas. Gauti tokie e. sveikatos paslaugų naudotojų portretai (žr. 2, 3 lenteles). 
2 lentelè. E. sveikatos paslaugų žinotojų ir naudotojų portretai

\begin{tabular}{|c|c|}
\hline E. sveikatos paslaugų žinotojų portretai & E. sveikatos paslaugų naudotojų portretai \\
\hline \multicolumn{2}{|l|}{ Pacientų registracija pas gydytoją internetu } \\
\hline $\begin{array}{l}\text { - Moteris, gyvenanti didmiestyje } \\
\text { - Jauna, } 18-29 \text { metų } \\
\text { - Studijuojanti universitete ar jau igijusi aukš- } \\
\text { tajji išsilavinimą } \\
\text { - Gali būti ištekèjusi } \\
\text { - Namų ūkyje gyvena } 3 \text { ir daugiau vaikų iki } \\
17 \text { metų } \\
\text { - Vienam šeimos nariui tenka didelès paja- } \\
\text { mos, } 1001 \text { Lt ir daugiau } \\
\text { - I ASPI per pastaruosius dvejus metus krei- } \\
\text { pėsi nedažnai, nuo } 2 \text { iki } 5 \text { kartų }\end{array}$ & $\begin{array}{l}\text { - Jaunas } 18-29 \text { metų didmiesčio gyventojas } \\
\text { - Nevedęs ar neištekejusi, šeimos ūkyje gyve- } \\
\text { na vienas vaikas (iki } 17 \text { metų) } \\
\text { - Studijuojantis universitete ar jau igijęs } \\
\text { aukštąji išsilavinimą } \\
\text { - I ASPI per pastaruosius dvejus metus krei- } \\
\text { pėsi nedažnai, nuo } 2 \text { iki } 5 \text { kartų }\end{array}$ \\
\hline \multicolumn{2}{|c|}{ Pacientas gauna priminimą apie vizitą pas gydytoją SMS žinute ar el. paštu } \\
\hline $\begin{array}{l}\text { - Moteris, gyvenanti didmiestyje } \\
\text { - Jauna, } 18-29 \text { metų } \\
\text { - Studijuojanti universitete ar jau igijusi aukš- } \\
\text { tąji išsilavinimą } \\
\text { - Netekejusi } \\
\text { - Namų ūkyje gyvena } 3 \text { ir daugiau vaikų iki } \\
17 \text { metų } \\
\text { - Vienam šeimos nariui tenka didelès paja- } \\
\text { mos, } 1001 \text { Lt ir daugiau } \\
\text { - I ASPI per pastaruosius dvejus metus krei- } \\
\text { pėsi nedažnai, nuo } 2 \text { iki } 5 \text { kartų }\end{array}$ & $\begin{array}{l}\text { - Jaunas } 18-29 \text { metų didmiesčio gyventojas } \\
\text { - Turintis aukštaji išsilavinimą, tačiau yra } \\
\text { bedarbis } \\
\text { - Nevedęs ar neištekejusi } \\
\text { - I ASPI per pastaruosius dvejus metus krei- } \\
\text { pesi nedažnai, nuo } 2 \text { iki } 5 \text { kartų }\end{array}$ \\
\hline
\end{tabular}

3 lentelè. E. sveikatos paslaugos „Gydantis gydytojas pildo nedarbingumo lapelị el. būdu“ žinotojo ir naudotojo portretai

Gydantis gydytojas pildo nedarbingumo lapelị el. būdu

\begin{tabular}{|c|c|}
\hline E. sveikatos paslaugų žinotojų portretai & E. sveikatos paslaugų naudotojų portretai \\
\hline $\begin{array}{l}\text { - Didmiesčio gyventojas, vedęs ar ištekèjusi } \\
\text { - Vidutinio amžiaus, } 40-49 \text { metų } \\
\text { - Turi aukštajji išsilavinimą } \\
\text { - Užima aukštas pareigas, yra verslininkas } \\
\text { (-è) ar vadovas (-è) } \\
\text { - Namų ūkyje gyvena vienas du vaikai iki } 17 \\
\text { metų } \\
\text { - Vienam šeimos nariui tenka didelès paja- } \\
\text { mos, } 1001 \text { Lt ir daugiau } \\
\text { - I ASPI per pastaruosius dvejus metus krei- } \\
\text { pėsi nedažnai, nuo } 2 \text { iki } 5 \text { kartų }\end{array}$ & $\begin{array}{l}\text { - Didmiesčio gyventojas } \\
\text { - Vidutinio amžiaus, } 40-49 \text { metų } \\
\text { - Turintis aukštąji išsilavinimą } \\
\text { - Yra specialistas ar darbininkas } \\
\text { - Vienam šeimos nariui tenka didelès paja- } \\
\text { mos, } 1001 \text { Lt ir daugiau } \\
\text { - Išsiskyręs (-usi) } \\
\text { - I ASPI per pastaruosius dvejus metus krei- } \\
\text { pėsi nedažnai, nuo } 2 \text { iki } 5 \text { kartų }\end{array}$ \\
\hline
\end{tabular}


Šios e. sveikatos paslaugos naudotojo portretas išsiskiria iš kitų, kadangi naudojimasis šia paslauga nepriklauso nuo laisvo naudotojo pasirinkimo. Šia paslauga daugiau naudojasi tie gyventojai, kurie dažniau serga, todèl yra priversti kreiptis $\mathfrak{i}$ gydytojus dèl nedarbingumo. Būtent tokio amžiaus asmenų padidèja sergamumas įvairiomis ligomis, traumų ir nelaimingų atsitikimų rizika.

Taip pat išrinkus dominuojančius demografinius-socialinius požymius, gautas toks dažnai besinaudojančio sveikatos priežiūros paslaugomis gyventojo portretas (žr. 4 lentelę).

4 lentelè. Dažnai besinaudojančio sveikatos priežiūros paslaugomis gyventojo portretas

Dažnai besinaudojančio sveikatos priežiūros paslaugomis gyventojo portretas

- Didmiestyje gyvenanti moteris

- Vyresnio amžiaus, turinti 60 metų ir daugiau, nedirbanti arba neigali pensininkè

- Igijusi specialųji viduriniji ar aukštesnijj išsilavinimą

- Ištekejjusi, namų ūkyje negyvena nè vienas vaikas (iki 17 metų)

- Vienam šeimos nariui tenka vidutiniškai nuo 601 iki $1000 \mathrm{Lt}$

- Dažniausiai lankosi valstybinèse ASPI

Tyrimas padejo pagrindą tolesniems e. sveikatos paslaugų naudotojų portretų ir personų tyrimams. Kadangi, kaip jau ir buvo minèta, naudotojo portretas yra pirmas ir svarbus žingsnis siekiant nustatyti, kokie asmenys turètų būti įtraukti ị paslaugos ar produkto projektavimą, šiuo atveju e. sveikatos paslaugų kūrimą ir plètrą Lietuvoje.

\section{Išvados}

1. Tyrimo metu pavyko iggyvendinti užsibrežtą tikslą ir nustatyti dviejų rūšių sveikatos paslaugomis besinaudojančiųjų portretus: e. sveikatos paslaugas naudojančio portretas bei dažnai sveikatos priežiūros paslaugomis besinaudojančio gyventojo portretas. Galima pastebèti, kad e. sveikatos paslaugų naudotojų ir sveikatos priežiūros paslaugų naudotojo portretai yra labai skirtingi. Manome, kad iš šio tyrimo galima daryti prielaidą, kad dabartinès e. sveikatos paslaugos Lietuvoje netenkina statistinio Lietuvos gyventojo, o tuo labiau dažno sveikatos priežiūros paslaugų naudotojo. Išsamesne šios problemos analizè galètų būti atlikta kituose tyrimuose.

2. Portretų tyrimai parodè, kad egzistuoja gan objektyvūs socialiniai-demografiniai netolygumai tarp e. sveikatos paslaugų naudotojų, kurie aiškiai rodo netolygumus ir e. sveikatos plètroje. E. sveikatos paslaugos kokybiškiau veikia dideliuose miestuose, kokybiškesnè internetinė prieiga yra pasiekiama didesnių pajamų, aukštesnio išsilavinimo, ir jaunesnių gyventojų grupei. Tuo tarpu e. paslaugų poreikis kitoms amžiaus grupèms yra net labiau reikalingas dèl didesnio sveikatos paslaugų poreikio. Tad portretų socialnių-demografinių netolygumų stebėsena leidžia nustatyti e. sveikatos sistemos vystymosi spragas, kurios gali būti siūlytinos tobulinti pirmiausia. 
Padèka. Straipsnis parengtas pagal mokslinio tyrimo, finansuojamo Europos socialinio fondo léšomis pagal visuotinès dotacijos priemonę, medžiaga (projektas „E-sveikatos pletros integruotos transformacijos: suinteresuotuju pusiu tinklo perspektyva", projekto kodas VP1-3.1-ŠMM-07-K-02-029).

\section{Literatūra}

1. Abras, C.; Maloney-Krichmar, D.; Preec, J. User-Centered Design. In Bainbridge, W. Encyclopedia of Human-Computer Interaction. Thousand Oaks: Sage Publications, 2004.

2. Andreassen, H. K., et al. European citizens' use of E-health services: A study of seven countries. BMC Public Health, 2007, 7: 53.

3. Cooper, A.; Reimann, R.; Cronin, D. About Face, 3rd ed. The Essentials of Interaction Design. Wiley Publishing, Inc., Indianapolis, IN, 2007.

4. Dayton, D. Audiences involved, imagined, and invoked: trends in user-centered interactive information design. In Professional Communication Conference. IPCC 2003, IEEE International, Piscataway, NJ, 2003.

5. Kairys, J., et al. Pacientų nuomonè apie informacinių technologijų panaudojimą Vilniaus miesto Centro ir Šeškinès poliklinikose pagal pacientų amžių. Medicinos teorija ir praktika. 2011, 11 (1): 55-64.

6. Karapanos, E.; Martens, J. B. Characterizing the Diversity in Users' Perceptions HumanComputer Interaction - INTERACT 2007, The Netherlands, Eindhoven, Eindhoven University of Technology, LNCS 4662, Part I, 2007, p. 515-518.

7. LeRouge, C., et al. User profiles and personas in the design and development of consumer health technologies, Int. J. Med. Inform. (2011), doi:10.1016/j.ijmedinf.2011.03.006

8. Lietuvos Respublikos sveikatos apsaugos ministro įsakymas Valstybés žinios. 2007, Nr. 108-4430.

9. Lietuvos Respublikos sveikatos apsaugos ministro įsakymas. Valstybès žinios. 2010, Nr. 21-1015.

10. Pruitt, J.; Adlin, T. The Persona Lifecycle: Keeping People in Mind Throughout Product Design. Morgan Kaufmann Publishers, San Francisco, CA, 2006.

11. Stašys, R. Elektroninès sveikatos paslaugos ir jų poreikio vertinimas. Verslas, vadyba ir studijos. 2009, p. 246-260.

12. van Velsen L., et al. Personas: The Linking Pin in Holistic Design for eHealth. eTELEMED 2012: The Fourth International Conference on eHealth, Telemedicine, and Social Medicine, 2012.

13. Weingart, S. N.; Rind, D.; Tofias, Z.; Sands, D. Z. Who Uses the Patient Internet Portal? The PatientSite Experience. Journal of the American Medical Informatics Association. 2006, 13 (1): 91-95.

\section{E-health Services "User Profile" in Lithuania}

Eglè Caronkutè, Birutė Mikulskienè

Mykolas Romeris University, Lithuania

Summary. Introduction. The development of Lithuanian e-health system underwent quite a few challenges and fails when the effort did not bring the expected result. However, it is worth mentioning a few major breakthroughs creating its separate parts. To improve the e-health 
system purposefully and to increase the popularity of using e-health system, it is needed to have specific knowledge about the drawbacks of the system. The users and their willingness to use the created systems are the best reflection of the accessibility of e-health. "User profile" reveals characteristic target user group features and lets to predict other users behaviour in the future. "User profile" is one of the recognised means to improve e-services.

Objective. The objective of the research, presented in the article, is to determine e-health services "user profile" or "profiles", ascertaining which e-health services "user profile" is satisfied with the current e-health system in Lithuania.

Methods and data. One thousand inhabitants who know and use e-health services in Lithuania were questioned to determine e-health "user profile" or "profiles" in Lithuania. The necessary empirical data were given by the project "Integrated Transformation of E-Health: Perspectives of Stakeholders' Network" VP1-3.1-ŠMM-07-K-02-029/2013, which performed the quantitative survey of Lithuanian inhabitants. Secondary analysis of quantitative data method was applied to analyse the data. Statistical data analysis was performed using the statistical package "SPSS" (Version 17), "WinPepi" and "Microsoft Excel 2010" programmes. The using of the services was analysed according to the socio-demographical characteristics, i.e. gender, living place, age, education, occupation, family status, number of the family members and income. The frequency of using healthcare services, and the fact which healthcare institutions private or state - were attended, was also taken into consideration.

Results. During the research the objectives were reached and two types of health services were revealed: $e$-health services "user profiles" and the "profile" of a frequent healthcare user in Lithuania. It is noted that e-health service users and healthcare services "user profiles" are very different. The research of the "profiles" showed that there are objective socio-demographical inequalities between e-health users, which clearly show inequalities in e-health development. E-health services function more effectively in bigger cities; internet connection is more accessible for people with higher income, better education and younger inhabitants. Meanwhile, the need for e-services in other age groups is even more necessary because of the greater demand in healthcare. Summing up, socio-demograpical inequalities in "user profiles" allows to determine e-health system development drawbacks, which could be suggested for further improvement as the priority.

Keywords: $e$-health, e-health services, user profile.

Eglè Caronkutè, Mykolo Romerio universiteto Politikos ir vadybos fakulteto Vadybos instituto magistrè. Mokslinių tyrimų kryptys: e. sveikata, sveikatos priežiūros skirtumai, sveikatos priežiūros paslaugų kokybè.

Eglè Caronkutè, Mykolas Romeris University, Faculty of Politics and Management, Institute of Management, Master student. Research interests: e-health, health inequalities, health care services quality.

Birutė Mikulskienė, Mykolo Romerio universiteto Politikos ir vadybos fakulteto Vadybos instituto profesorè, fizinių mokslų daktarè. Mokslinių tyrimų kryptys: sprendimų prièmimas, e. sveikata, suinteresuotųjų šalių vadyba.

Birutė Mikulskienė, Doctor of Physical Sciences, Mykolas Romeris University, Faculty of Politics and Management, Institute of Management, Professor. Research interests: decisionmaking, e-health, stakeholder management. 